УДК 616.36-001.-08.

DOI

(с) В. с. ЖУКОВСькИЙ

Львівський національний медичний університет ім. Данила Галицького

Львівська міська клінічна лікарня № 8

\title{
Лікува.љна тактика при травматичних пошкодженнях печінки
}

\author{
V. S. ZHUKOVSKYI \\ Lviv National Medical University by Danylo Halytskyi \\ Lviv Municipal City Hospital № 8
}

\section{MEDICAL MANAGEMENT OF LIVER TRAUMA}

\begin{abstract}
У статті наведено результати лікування 123 потерпілих із травматичним пошкодженням печінки, з яких у 76 (61,8 \%) діагностовано ізольоване пошкодження печінки; у 47 (38,2 \%) - множинні пошкодження органів черевної порожнини. Oб'єм операційного втручання був зумовлений тяжкістю пошкодження печінки за OIS. Операційні втручання за технологією “damage control” проведено 7 потерпілим, 3 пацієнтам виконано атипову резекцію печінки. Реінфузію крові проведено 71 травмованому. Післяопераційні ускладнення розвинулись у 13 пацієнтів. Померли 14 потерпілих.

The article presents the results of treatment of 123 victims with traumatic liver damage from whom isolated liver damage was diagnosed in $76(61.8 \%)$ and multiple damage of the abdominal cavity in $47(38.2 \%)$. The amount of surgery was due to the severity of liver damage by OIS. Operating interferences by technology of "damage control" conducted on 7 victims, 3 - atypical liver resection. Reinfusion of blood was carried in the 71 injured. Postoperative complications developed in 13 patients. 14 victims died.
\end{abstract}

Постановка проблеми і аналіз останніх досліджень та публікацій. Травма органів черевної порожнини залишається однією зі складних та актуальних проблем хірургії. Травматичні пошкодження печінки при абдомінальній травмі посідають друге місце після травми селезінки $[1,2,17]$. Частота пошкоджень печінки при проникаючих пораненнях та закритих травмах живота складає $12-47 \%[1,3,14]$. Летальність при закритій травмі печінки сягає $50 \%$, вогнепальних пораненнях - 46,1 \%, колото-різаних - 10,5 \% [3, 6, 12]. Слід врахувати, що велика кількість потерпілих гине на місці травми або під час транспортування. Основною причиною летальних наслідків при травмі печінки є масивна внутрішньочеревна кровотеча, тому своєчасності операційного втручання та вибору адекватного методу гемостазу приділяють особливе значення. При цьому хірург повинен звести до мінімуму небезпеку розвитку тяжких внутрішньочеревних ускладнень, частота яких може сягати $17-33 \%[4,11]$.

Мета роботи: покращення результатів лікування травмованих з пошкодженням печінки методом диференційованого підходу до вибору об'єму операційного втручання та методу гемостазу.

Матеріали і методи. Проведено ретроспективний аналіз лікування 123 потерпілих із трав- матичним пошкодженням печінки, які перебували на стаціонарному лікуванні у Львівській міській клінічній лікарні № 8. 3 них 96 пацієнтів (78,1 \%) складали чоловіки, 27 хворих (21,9 \%) жінки. Середній вік потерпілих складав 39 років (68,9 \%). Розрив печінки внаслідок закритої травми черевної порожнини діагностовано у 78 хворих (63,4 \%), поранення - у 45 (36,6 \%) пацієнтів (колото-різані - 42, вогнепальні - 3). При розривах печінки поєднана травма мала місце у 87 (70,7 \%) постраждалих, при цьому переважно під час автодорожніх пригод - у 52 (59,8 \%) чи падіннях з висоти - у 15 (17,2 \%) осіб.

Тяжкість стану потерпілих була зумовлена як характером пошкодження печінки та інших органів, так і величиною крововтрати. У 19 осіб $(15,4$ \%) були ознаки шоку I ступеня, у 76 (61,8 \%) - II ступеня і у 28 (22,8 \%) - III ступеня.

Пацієнтів із нестабільною гемодинамікою відразу після госпіталізації скеровували в операційну, де їм катетеризували магістральну вену і проводили протишокову терапію. Паралельно виконували клінічні обстеження, катетеризацію сечового міхура, рентгенографію голови, грудей, таза, пункцію плевральної порожнини і лапароцентез. Пацієнтам із стабільною гемодинамікою проводили всебічне обстеження для повної діагностики всіх пошкоджень. 


\section{З ДОСВІДУ РОБОТИ}

Діагностика відкритих пошкоджень печінки базувалася на локалізації рани в зоні проекції органа, клінічній картині кровотечі з відповідними змінами параметрів гемодинаміки та лабораторних показників. При наявності проникаючих ран нижніх відділів грудної клітки, з метою виключення торако-абдомінального поранення, обстеження доповнювали лапароцентезом. При закритій травмі на пошкодження печінки вказували: аналіз обставин травми, скарги потерпілого, наявність клінічної картини внутрішньочеревної кровотечі, дані зовнішнього огляду та інструментальних методів обстеження. Клінічні ознаки травми печінки залежали від характеру та ступеня пошкодження паренхіми, її судин та жовчних проток. Для визначення хірургічної тактики при травматичних пошкодженнях печінки використовуємо міжнародну шкалу пошкоджень органів - Organ Injury Scale (OIS), запропоновану Американською асоціацією хірургів травми - AAST [16]. Згідно з цією шкалою пошкоджень печінки виділяють такі ступені тяжкості пошкоджень: I ст. - підкапсульна гематома $<10$ \% поверхні, розрив капсули, паренхіми глибиною <1см; II ст. - підкапсульна гематома 10-50 \% поверхні, внутрішньопечінкова гематома $<10$ см у діаметрі, розрив паренхіми глибиною 1-3 см, довжиною <10 см; III ст. - підкапсульна гематома $>50$ \% поверхні, внутрішньопечінкова гематома $>10$ см, розрив паренхіми глибиною $>3$ см; IV ст. - розрив паренхіми охоплює 25-75 \% частки печінки або 1-3 сегменти в окремій частці; V cт. - розрив паренхіми більше 75 \% частки печінки або більше 3 сегментів в окремій частці, ушкодження позапечінкових вен, центральних, великих печінкових вен, відрив печінки.

Результати досліджень та їх обговорення. Оптимальним доступом при пошкодженнях печінки вважаємо серединну лапаротомію. Маніпуляції на 7-8 сегментах печінки ставали можливими після пересічення зв'язкового апарату печінки з наступною тракцією органа за куксу круглої зв'язки. При неможливості проведення маніпуляцій проводили додатковий розтин тканин у 8-му міжребер'ї з діафрагмотомією, яку потім ушивали. Трансдіафрагмальна лапаротомія проведена у 6 травмованих.

Під час операційних втручань у 76 (61,8 \%) хворих діагностовано ізольоване ушкодження печінки; у 47 (38,2 \%) пацієнтів - множинні пошкодження органів черевної порожнини. Ушкодження печінки були в поєднанні з розривами: селезінки - 9 (19,1 \%), кишки - 7 (14,9 \%), брижі кишки - 8 (17,02 \%), діафрагми - 3 (6,4\%), сечового міхура - 2 (4,3 \%). Ушкодження трьох і більше органів черевної порожнини діагностовано у 18 (38,3%) випадках.

За ступенем тяжкості ушкодження печінки травмовані розподілилися таким чином: I ст. -12 (9,7 \%) потерпілих, II ст. - 56 (45,6 \%), III ст. - 38 (30,9 \%), IV ст. - 12 (9,7 \%), V ст. - 5 (4,1\%).

Ушкодження правої частки печінки було констатовано в 86 (69,9 \%) хворих, лівої частки - в 24 (19,5 \%), в 13 (10,6 \%) випадках виявлено ушкодження обох часток. Частіше травмувалися III, IV, V i VI сегменти.

Об'єм операційного втручання був зумовлений тяжкістю ушкодження печінки. При закритій травмі печінки I-II ступенів тяжкості, як і при ножових пошкодженнях печінки основним хірургічним втручанням було ушивання розриву або рани печінки. Такий же об'єм операційного лікування проведено у 35 із 38 потерпілих із травмою печінки III ступеня тяжкості, при цьому у 8 із них - у поєднанні з тампонадою рани сальником на судинній ніжці. Також 3 метою гемостазу використовували гемостатичні пластинки “Тахокомб” та гемостатичну губку.

При вогнепальних пораненнях у 3 (2,4 \%) потерпілих висікали нежиттєздатні тканини, видаляли сторонні тіла з подальшим ушиванням рани. У 11 хворих з глибокими розривами печінки неправильної форми і триваючою інтенсивною кровотечею, досягнувши тимчасового гемостазу перетисненням гепатодуоденальної зв'язки (у 8) або накладанням турнікету (у 3), прошивали пошкоджені судини безпосередньо в рані. Потім проводили хірургічну обробку ран печінки, видаляли детрит. В умовах “сухої” рани перевіряли цілість внутрішньопечінкових жовчних проток.

Об'єм внутрішньочеревної кровотечі до 500 мл мав місце у 22 (17,8 \%) травмованих, до 1000 мл - у 28 (22,8 \%), понад 1000 мл - у 73 (59,4 \%) пацієнтів. Реінфузію крові проведено 71 (57,7 \%) травмованому, решті пацієнтам реінфузії не виконували через ушкодження порожнистих органів, наявність гемолізу або масивних згустків крові.

Зупинити кровотечу з розчавленої рани печінки прошиванням судин безпосередньо в рані вдається не завжди, особливо при травмі 7-8-го сегментів, коли можлива ще й ретроградна кровотеча з системи нижньої порожнистої вени; перетиснення гепатодуоденальної зв'язки в такій ситуації не ефективне. Резекція печінки у знекровленого постраждалого може стати смертельним для нього втручанням, тим більше в неспеціалізованому відділенні. В зв'язку з цим доцільним $є$ проведення гемостазу тампонадою рани марлевими серветками, що дозволяє стабілізувати гемодинаміку і закінчити опе- 
рацію в максимально короткі терміни - операційні втручання за технологією “damage control” $[10,11]$. 3 допомогою даного методу нам вдалося зупинити кровотечу в 7 потерпілих із закритою травмою печінки III-IV ступенів тяжкості. Тампони видаляли на 2-3 добу, після стабілізації стану пацієнта при релапаротомії. Проводили контроль гемостазу, видалення секвестрів, дренування ран печінки.

При закритій травмі печінки III-IV ступенів тяжкості 3 потерпілим проведено атипову резекцію 3 прикриттям ранової поверхні клаптем великого сальника: 2 (1,8 \%) пацієнтам виконано резекцію правої частки печінки і в 1 (0,9 \%) - лівої; результат добрий. У одного хворого ушито v. portae, y 4 (3,2 \%) пацієнтів видалено пошкоджений жовчний міхур, жовчовивідні протоки дреновано в 6 (4,9\%) потерпілих 3 метою профілактики жовчного перитоніту.

Для профілактики гіпоксії печінки в ранньому післяопераційному періоді особливу увагу приділяли корекції метаболічного ацидозу, своєчасному відновленню гемодинаміки, адекватній терапії крововтрати з корекцією реології крові, призначенню антигіпоксантів.

Післяопераційні ускладнення розвинулись у 13 пацієнтів. Найбільш частим ускладненням був перитоніт, зумовлений тяжкою травмою печінки та некрозом тканин у ділянці рани після її ушивання “ad massam”. Специфічними для травми печін-

\section{СПИСОК ЛІТЕРАТУРИ}

1. Альперович Б. И. Лечение травматических повреждений печени / Б. И. Альперович, В. Ф. Цхай // Анн. хир. гепатол. -2001. - № 1. - С. 36-39.

2. Современные методы хирургической коррекции массивных повреждений печени / В. Б. Бойко, И. А. Криворучко, Н. Н. Удербаев [та ін.] // Харківська хірургічна школа. - 2004. - № 3 (12). - С. 89-91.

3. Гарев Р. Н. Травматические повреждения печени и желчевыводящих путей / Р. Н. Гарев, Х. К. Нгуен // Медицинский вестник Башкортостана. - 2013. - Т 8, № 1. - С. 118-122.

4. Гешелин С. А. Принципы гемостаза во время операций по поводу травм печени / С. А. Гешелин // Анн. хир. гепатол. 1998. - № 3. - С. 208-211.

5. Диагностика и хирургическая тактика при травмах печени / В. И. Десятерик, С. П. Михно, Л. Н. Полищук [и др.] // Анн. хир. гепатологии. - 2003. - № 2. - С. 139.

6. Тяжелая травма печени: 25-летний опыт хирургического лечения / А. С. Ермолов, М. М. Абакумов, Е. С. Владимирова [и др.] // Анн. хир. гепатол. - 2007. - № 3. - С. 255.

7. Капшитарь А. А. Хирургическая тактика при закрытой травме печени / А. А. Капшитарь // Клінічна хірургія. - 2009. - № 5. - C. 17-19.

8. Множинні та поєднані ушкодження печінки при абдоміноскелетній травмі / Ф. М. Новіков, О. А. Ткаченко, О. В. Воробей [та ін.] // Хірургія України. - 2007. - № 3. - С. 42-45.

9. Сличко І. Й. Деякі питання лікувальної тактики при травматичних пошкодженнях печінки / I. Й. Сличко, ки ускладненнями також були: посттравматичний гепатит (у 2), піддіафрагмальний (у 2) і підпечінковий абсцес (в 1), абсцес печінки (у 2), жовчна нориця (у 2).

Хворим із піддіафрагмальними абсцесами та абсцесами печінки під контролем ультразвуку проводили пункцію та дренування гнояків. Санацію здійснювали шляхом промивання порожнини 0,5 \% розчином діоксидину, декасаном, розчинами антибіотиків залежно від виділеної мікрофлори та їі чутливості. Контрольні УЗД виконували на наступний день після пункції та дренування, а далі - за потребою. Хворий із підпечінковим абсцесом був повторно оперований, розкрито та дреновано абсцес.

Через вкрай тяжкий стан не оперовано 8 чоловік. Померли 14 (11,4 \%) потерпілих. Післяопераційна летальність зумовлена поєднаним характером ушкоджень, масивною зовнішньою і внутрішньою кровотечею, шоком і гострою дихальною недостатністю.

Висновок. Об’єм операційного втручання при травмі печінки повинен бути строго диференційованим відповідно до тяжкості пошкодження органа, показників гемодинаміки, інтенсивності кровотечі і спрямованим, перш за все, на забезпечення гемостазу з мінімальним для постраждалого життєвим ризиком.

Б. В. Доманський, I. О. Йосипенко // Український журнал екстремальної медицини імені Г. О. Можаєва. - 2003. - № 2. - C. 58-60.

10. Урман М. Г. Хирургическая тактика при травме печени и развившихся внутрибрюшных осложнениях / М. Г. Урман, А. В. Субботин // Вестник хирургии. - 2009. - Т. 168, № 3. C. $72-75$.

11. Perihepatic packing of major liver injuries / D. M. Caruso, F. D. Battistella, J. T. Owings [et al.] // Arch. Surg. - 1999. Vol. 134. - P. 958-963.

12. Feliciano D. V. Hepatic trauma / D. V. Feliciano, G. S. Rozycki // Scandinavian J. Surgery. - 2002. - Vol. 91. - P. 72-79.

13. Garrison J. R. Predicting the need to pack early for severe intraabdominal hemorrhage / J. R. Garrison, J. D. Richardson, A. S. Hilakos [et al.] // J. Trauma. - 1996. - Vol. 40. - P. 923-920.

14. Lawrence D. The secondary management of complicated liver injuries / D. Lawrence, J. L. Dawson // Ann Roy. Coll Sum Enol. - 1982. - Vol. 64, № 5. - P. 186-190.

15. A. M. Mohr, R. F. Lavery, A. Barone [et al.] Angiographic embolization for liver injuries: low mortality, high morbidity // J. Trauma. - 2003. - Vol. 55, № 6. - P. 1077-1081.

16. Organ injury scaling / E. E. Moore, T. H. Cogbill, M. A. Malangoni [et al.] // Surg. Clinics of North America. - 1995. - Vol.75. - P. 293-303.

17. Evolution in the management of hepatic trauma: a 25-year perspective / J. D. Richardson, G. A. Franklin, J. K. Lukan [et al.] // Ann. Surg. - 2000. - Vol, 232, № 3. -P. 324-330. 